\title{
Mastite bovina causada por Candida sp.: aspectos epidemiológicos e clínicos
}

\section{Bovine mastitis caused by Candida sp. : epidemiological and clinical aspects}

\author{
Rinaldo Aparecido Mota, ${ }^{*}$ Nivaldo de Azevedo Costa, ${ }^{\star \star}$ Andréa Alice da Fonseca Oliveira, ${ }^{\star \star *}$

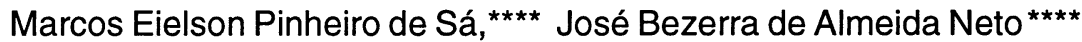

\section{Resumo}

Estudaram-se os aspectos epidemiológicos e clínicos da infecção da glândula mamária de bovinos causada pela Candida sp. Observou-se relação entre a infecção humana e o uso indiscriminado de antibióticos e desinfetantes com a manifestação clínica da doença nos animais.

Palavras-chave: mastite; bovinos; Candida sp.

\section{Introdução}

A mastite caracteriza-se pela inflamação aguda ou crônica da glândula mamária, independentemente de sua causa, determinando alterações físicas, químicas e bacteriológicas do leite (Blood e Radostits, 1991).

Os agentes etiológicos são predominantemente bacterianos, e em geral a principal fonte de infecção é a própria glândula mamária contaminada, sendo os microrganismos transmitidos pelas mãos do ordenhador, pelos copos da ordenhadeira e até através dos bezerros quando mamam (Corrêa e Corrêa, 1992; Langoni, 1996).

A ordenha manual, quando realizada corretamente e de forma higiênica, predispõe menos ao surgimento de mastites que a ordenha mecânica; entretanto, as mãos contaminadas podem levarà disseminação dos agentes infecciosos; dentre eles os mais comuns são: Staphylococcus aureus, Staphylococcus sp., Corynebacterium bovis, Streptococcus sp., Pseudomonas sp. entre outros (Faria et al., 1982; Costa et al., 1986, 1993).

Esporadicamente são isolados outros agentes, principalmente fungos e algas (Langoni, 1996).

Na mastite causada por Candida sp. é provável que a infecção seja por infusões intramamárias ou pelo contato com o revestimento de teteiras, contaminadas. $O$ estabelecimento de infecções é favorecido por lesões no epitélio mamário devido à ação de alguns antibióticos (penicilina e tetraciclina), que são fontes de nitrogênio para a levedu- ra (Schalm et al., 1971; Langoni et al., 1985; Blood e Radostits, 1991).

Mills e Hirth (1967) discutiram as teorias relativas ao aumento do crescimento de Candida sp. pelo uso prolongado de antibióticos. Propuseram várias hipóteses como: o estímulo direto do fungo, a eliminação de microrganismos competitivos por nutrientes e que produzem substâncias antifúngicas. Consideraram, ainda, a possibilidade de danos teciduais pelos antibióticos agressores, a conversão da Candida sp. a uma forma mais invasora, os produtos tóxicos elaborados pelos agentes e a depressão das respostas do hospedeiro à infecção.

Stuart (1951) isolou a Candida sp. em um surto que se desenvolveu após infusão intramamária com penicilina.

Prassad e Praśsad (1966) identificaram Candida parapsilosis no leite de casos de mastite após a terapia com antibióticos contra infecção bacteriana preexistente.

A identificação de leveduras envolvidas na etiologia da mastite bovina tornou-se mais freqüente nas últimas décadas com relatos feitos por Farnsworth e Sorensen (1972); Murphy e Drake (1974); Langoni et al. (1985); Oliveira et al.(1997).

O objetivo deste estudo foi relatar a ocorrência de um foco de mastite clínica e subclínica em bovinos causada pela Candida sp., seus aspectos epidemiológicos e clínicos, além da relação com a saúde pública.

\footnotetext{
* Prof. Adjunto-Doutor de Bacterioses dos Animais Domésticos - Departamento de Medicina Veterinária, UFRPE, Rua

Dom Manuel de Medeiros s/n, Dois Irmãos, Recife, PE, Brasil.

** Médico Veterinário - Clínica de Bovinos, UFRPE, Av. Bom Pastor, s/n, Garanhuns, PE, Brasil.

${ }^{\star \star \star}$ Pós-graduanda - Mestrado em Medicina Veterinária, UFRPE.

${ }^{\star \star * \star}$ Residentes da Clínica de Bovinos, UFRPE, Garanhuns, PE, Brasil.
} 


\section{Material e Métodos}

Visitou-se uma propriedade de exploração leiteira com bovinos oriundos de cruzamento de holandês com zebu, apresentando graus variados de sangue, localizada no Município do Cabo de Santo Agostinho-PE. A propriedade possuía cerca de 25 animais, sendo 12 vacas em diferentes números e estágios de lactação e número de partos variados. A queixa principal do proprietário relacionava-se a inflamações recidivantes na glândula mamária, tratadas anteriormente com as mais diversas drogas antimicrobianas (penicilina, estreptomicina, novobiocina, polimixina $B$, tetraciclina, gentamicina e cefalosporina) sem cura clínica dos casos. A anamnese revelou, ainda, que os tratamentos com antimastíticos eram feitos periodicamente.

A ordenha era realizada de forma manual com bezerro ao pé; adotava-se o pré-dipping com solução de hipoclorito de sódio, secagem das tetas com papel-toalha e examinavam-se os primeiros jatos de leite pela prova de tamis. No pós-dipping utilizavam-se produtos à base de amônia quaternária.

Foi observado que o ordenhador apresentava lesões pruriginosas e descamativas na face.

O exame clínico dos animais foi direcionado para a glândula mamária, detectando-se na inspeção o ressecamento e a presença de fissuras no tecido de revestimento das tetas. Na palpação observaram-se áreas de fibrose no parênquima mamário de alguns animais com mastite clínica.

As amostras de leite foram coletadas em tubos de ensaio esterilizados, após prévia lavagem das tetas com água e sabão, secagem com papel-toalha e anti-sepsia do óstio do teto com álcool a $70^{\circ}$.

Coletaram-se também amostras das lesões da face do ordenhador, através do raspado de pele.

Os primeiros jatos de leite foram utilizados para detectar alterações macroscópicas, como presença de grumos e pus. As amostras de leite que não indicaram evidência de mastite clínica foram submetidas ao California Mastitis Test (CMT), de acordo com Schalm e Noorlander (1957).

Coletaram-se amostras de leite com alterações macroscópicas e aquelas com CMT positivo $(1+, 2+\mathrm{e} 3+)$ para realização de exames microbiológicos.

As amostras de leite foram semeadas em ágar base, contendo $5 \%$ de sangue ovino e em ágar levine. As placas foram incubadas a $37^{\circ} \mathrm{C}$, em estufa bacteriológica, em condições de aerobiose, e as leituras foram efetuadas às 24, 48 e 72 horas de incubação.

A amostra de raspado de pele da face do ordenhador foi cultivada sob as mesmas condições, em ágar Saborauddextrose, em temperatura ambiente, realizando-se leituras diárias durante cinco dias. A identificação do agente foi realizada através das características culturais e morfotintoriais pela técnica de coloração do Gram.

Observou-se o crescimento de colônias brancas, circulares, convexas, com cerca de $1 \mathrm{~mm}$ de diâmetro, identificadas às 48 e 72 horas de incubação. Na microscopia das lâminas coradas pelo Gram, observaram-se células leveduriformes com brotamento e fortemente Gram positi- vas, identificando-se o agente presuntivamente como sendo pertencente ao gênero Candida sp. (Figura 1).

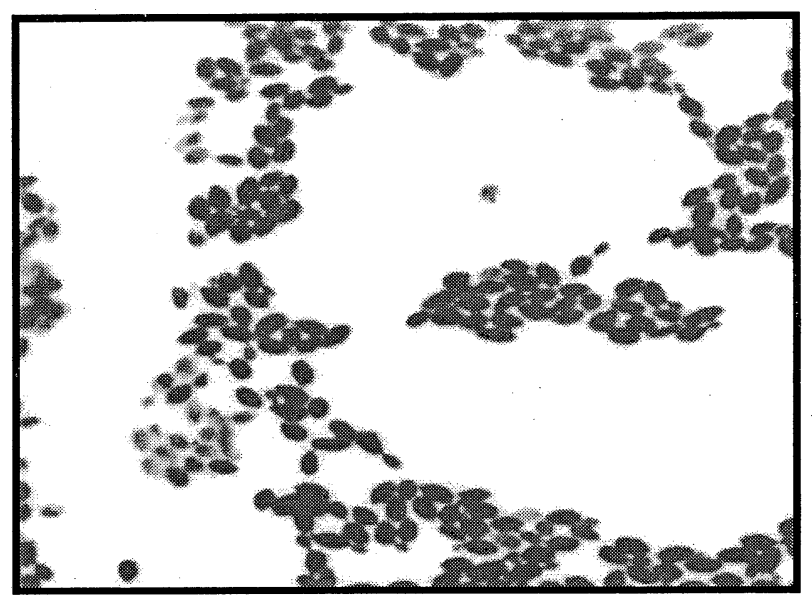

Figura 1: Candida sp. isolada de secreção láctea de vacas com mastite clínica e subclínica

Os mesmos critérios foram utilizados para o estudo da etiologia das lesões de pele do ordenhador, observando-se que o agente isolado tinha características morfológicas semelhantes às do agente isolado das amostras de leite.

\section{Resultados}

Os dados relativos ao resultado obtido no CMT e no exame microbiológico do leite das 40 amostras estudadas mostraram que $50 \%$ delas apresentaram reações positivas ao CMT nos escores $1+, 2+$ e 3+, e $50 \%$ destas mostraram-se positivas ao exame microbiológico (Tabela 1).

Tabela 1: Resultado do California Mastitis Testpor quarto mamário e exame microbiológico da secreção láctea de vacas com mastite clínica e subclínica

\begin{tabular}{cccccc}
\hline $\mathrm{VACA}$ & $\mathrm{AD}$ & $\mathrm{AE}$ & $\mathrm{PD}$ & $\mathrm{PE}$ & $\begin{array}{c}\text { Resultado do exame } \\
\text { microbiológico }\end{array}$ \\
\hline $\mathrm{N}^{\circ} 08$ & - & - & - & - & Staphylococcus $s p$. \\
$\mathrm{N}^{\circ} 06$ & + & - & + & +++ & Candida $s p$. \\
$\mathrm{N}^{\circ} 09$ & - & - & ++ & - & Candida $s p$. \\
$\mathrm{N}^{\circ} 03$ & - & ++ & +++ & + & Candida $s p$. \\
$\mathrm{N}^{\circ} 02$ & - & +++ & - & ++ & Candida $s p$. \\
$\mathrm{N}^{\circ} 05$ & ++ & - & - & - & Candida $s p$. \\
$\mathrm{N}^{\circ} 04$ & ++ & + & +++ & +++ & Candida $s p$. \\
$\mathrm{N}^{\circ} 19$ & +++ & ++ & ++ & ++ & Bacillus $s p$. \\
$\mathrm{N}^{\circ} 21$ & ++ & + & - & - & Staphylococcus $s p$. \\
$\mathrm{N}^{\circ} 20$ & + & + & - & ++ & Candida $s p$. \\
\hline
\end{tabular}

\section{Discussão}

Apesar da adoção de medidas higiênicas consideradas adequadas para a redução da flora patogênica da glândula mamária e agentes ambientais que podem estar envolvidos com processos inflamatórios do úbere, o proprietário exagerava nas concentrações dos produtos utilizados no pré e pós-dipping. Este fato pode ter contribuído para 0 
aparecimento de lesões irritativas e descamativas do epitélio de revestimento das tetas, como constatado na inspeção das glândulas mamárias. As lesões no epitélio mamário associadas ao uso indiscriminado de antibióticos possivelmente foram fatores predisponentes para a infecção dos quartos mamários, estando estas observações de acordo com as citações feitas por Shalm et al. (1971) ; Langoni et al. (1985); Blood e Radostits (1991).

O estudo epidemiológico realizado na propriedade demonstrou, através de minuciosa análise efetuada no ambiente onde ocorria a ordenha, que o ordenhador apresentava lesões pruriginosas e descamativas da pele na região do contorno dos lábios, queixo e testa, além do couro cabeludo. O isolamento de Candida sp. de material colhido das áreas lesadas sugere a participação do homem como fonte de infecção, dentro da cadeia epidemiológica de transmissão do agente às fêmeas durante a ordenha, onde este se coçava e levava o agente ao canal galactóforo aberto e lesado, favorecendo a infecção, como citado por Faria et al. (1982) e Costa et al. (1986, 1993).

Com relação à manifestação clínica das mastites por Candida $s p$., observou-se neste estudo que os sinais eram restritos aos úberes, que se apresentavam edemaciados, doloridos, hiperêmicos, com secreção láctea mostrando grumos, pus e estrias de sangue. A forma crônica da doença também foi observada na propriedade através da palpação dos úberes e detecção de cordões endurecidos no parênquima, compatíveis com áreas de fibrose. Constataram-se, também, atrofias de quartos mamários na fase mais avançada da mastite crônica. Os sinais clínicos observados na fase aguda e crônica são compatíveis com a descrição feita por Langoni et al. (1985).

Os animais que apresentavam mastite clínica foram tratados, utilizando-se infusões intramamárias à base de nistatina e timerosal durante sete dias consecutivos, de acordo com Langoni et al. ( 1985 ), observando-se pouca resposta nos quartos que apresentavam quadro clínico mais pronunciado.

As medidas relativas ao controle da doença no plantel basearam-se na retirada do ordenhador da ordenha, seu encaminhamento ao serviço médico especializado, eliminação dos animais com mastite, além de adoção de medidas higiênicas no ambiente.

Somente após o afastamento do ordenhador para tratamento é que se verificou a ausência de novos casos clínicos de mastite no plantel, ressaltando-se, mais uma vez, a importância deste na epidemiologia das mastites.

\section{Abstracts}

Studying the epidemiological and clinical aspects of mammary glands' infection caused by Candida sp., it was observed your relationship with human infection and the use of antibiotics and disinfectants without control.

Keywords: bovine; mastitis; Candida sp.

\section{Referências Bibliográficas}

BLOOD, D. C., RADOSTITS, O. M. Clínica Veterinária. 7. ed. Rio de Janeiro: Guanabara Koogan, 1991. 1263 p.

CORRÊA, W. M., CORRÊA, C. N. M. Enfermidades Infecciosas dos Mamíferos Domésticos. 2. ed. Rio de Janeiro: MEDSI, 1992. $843 \mathrm{p}$.

COSTA , E. O. , COUTINHO, S. D., CASTILHO, W. et al. Etiologia bacteriana de mastite bovina no Estado de São Paulo, Brasil. Rev. Microbiol., v. 17, p. 107-112, 1986 .

COSTA, E. O., ABE, S. Y., MELVILLE, P. A. Isolamento de alga do gênero Prothotheca sp. ( $\left.30.10^{3} \mathrm{UFC} / \mathrm{ml}\right)$ do leite de resfriador de propriedade tipo $\mathrm{B}$ e o potencial de risco à saúde pública. In: CONGRESSO INTERNACIONAL DE MEDICINA VETERINÁRIA EM LÍNGUA PORTUGUESA, 6 , Salvador, Dezembro de 1993. Anais... p. 20. Salvador.

FARIA, J. E., FIGUEIREDO, J. B., SANTOS, J. L. dos. Freqüência de patógenos e desinfecção das mãos dos ordenhadores. Arq. Esc. Vet. UFMG., v. 34, n. 4, p. 515-521, 1982.

FARNSWORTH, R. J., SORENSEN. D. K. Prevalence and species distribuition of yeasts in mammary glands of dairy cows in Minnesota. Canadian Journal of Comparative Medicine, Otawa, v. 36, p. 239-332, 1972.

LANGONI, H. Apostila da Disciplina de Zoonoses da FMVZ UNESP - Botucatu. 1996.
LANGONI, H., CORREAA, C. N. M., CORRÊA, W. M. et al. Mastites bovinas por Candida e Klebsiella. Rev. Bras. Med. Vet., v. 7 , n. 7, p. 203-204, 1985.

MILLS, J. H. L., HIRTH, R. S. Systemic candidiasis in calves on prolonged antibiotic therapy. Journal of American Veterinary Medicine Associated, v. 150, p. 862-870, 1967.

MURPHY, J. M., DRAKE, C. Infection of the bovine udder with yeastlike fungi. American Journal of Veterinary Research, Chicago, v. 8, p. 43-51, 1974.

OLIVEIRA, A. A. F., SÁ, M. E. P., SANTOS, A. P. F. et al. Relato de caso de mastite bovina por Candida sp. no Município de Canhotinho, agreste de Pernambuco. In: CONGRESSO BRASILEIRO DE MEDICINA VETERINÁRIA, 25, 1997, Gramado, Anais... p 34. Gramado.

PRASSAD, L. B. M., PRASSAD, S. Bovine Mastitis caused by a yeast. Indi. Vet. Rec., v. 79, p. 809-810, 1966.

SCHALM, O.W., NOORLANDER, D. D. Experiments and observations leading to development of the California mastitis Test. JAVMA, v. 130, p. 199-204, 1957.

SCHALM, O. W., CARROLL, E. J., JAIN, N. C. Bovine Mastitis. Philadelphia: Lea e Febiger, 1971. 360 p.

STUART, P. An outbreak of bovine mastitis from which yeasts were isolated and attempts to reproduce the conditions experimentally. Vet. Rec., v. 63, p. 314, 1951. 